\title{
Explaining Inequality in the Implementation of Asylum Law
}

\author{
Peter Mascini
}

\begin{abstract}
The goal of this research was to identify factors that account for procedural and substantive inequality in implementing asylum law. The decisions of ninety-eight caseworkers of the Dutch Immigration and Naturalization Service on an asylum application were related to their answers on a questionnaire. Caseworkers differ in the extent of available information on an asylum application they take for granted and in their final decisions on it. These differences result from work pressure, the caseworkers' reputation, their role definition, political opinion, and professional background, and policy. Intensifying feedback and decreasing work pressure can achieve more consistent and careful decisions.
\end{abstract}

\section{Résumé}

Le but de cette étude était d'identifier les facteurs responsables pour les inégalités de fond ainsi que des inégalités relatives à la procédure dans l'application de la loi sur le droit d'asile. Les décisions de quatre-vingt dix-huit agents chargés du cas du Service néerlandais pour l'immigration et la naturalisation concernant une demande d'asile furent reliées à leurs réponses à un questionnaire. Les agents chargés $d u$ cas different sur la somme d'information dont ils disposent concernant une demande d'asile qu'ils tiennent pour acquis et aussi dans leurs décisions finales concernant la même demande. Ces différences sont causées par la tension au travail, la réputation de lagent chargé du cas, leur définition de leur rôle, leurs opinions politiques, leurs antécédents professionnels et les politiques en place. Accroître la rétroaction et faire baisser la tension au travail aideront à atteindre des décisions plus cohérentes et consciencieuses.

\section{Introduction}

The predominant opinion in the literature on the implementation of law is that the translation of general laws in decisions about specific cases unavoidably leaves room for choices. ${ }^{1}$ This is called discretion. On the one hand, the freedom of choice enables officials to individualize decisions. This means that they can take into account more characteristics of a case than are formally relevant. On the other hand, it can lead to inequality before the law. This means that officials decide differently on comparable cases. Inequality before the law can refer either to the decision procedure or to the substance of the decision. ${ }^{2}$

The best way to study the individualization of decisions is to ask the same officials to decide upon different cases that are formally identical, but that differ in other respects. In this way it is possible to find out, for example, whether they are more likely to grant a disablement benefit for a sick breadwinner with years of work experience than for an inexperienced single person with the identical sickness. The relation between the use of discretion and inequality before the law can best be studied by asking different officials to decide on one identical case. Then it is clear from the start that all eventual different outcomes are unrelated to the legitimacy of the application itself. This paper is directed exclusively to the inequality before the law that can result from the use of discretion. The goal is to find causes of procedural and substantive inequality. For this reason ninety-eight officials responsible for the implementation of asylum policy in the Netherlands-socalled decision employees-were presented an identical fictitious asylum application and were asked what they would decide on it. ${ }^{3}$ Subsequently, these answers were connected to their answers on a questionnaire.

The implementation of asylum policy is a suitable subject for finding out how discretion results in procedural and substantive inequality. On the one hand, previous research has already demonstrated that both forms of inequality are 
no exception in relation to the implementation of asylum policy. Regarding procedural inequality, $\mathrm{Smit}^{4}$ has shown, for example, that decision employees indeed only request a test to establish the age of minor asylum seekers if there are serious doubts about the stated age, but that in some cases where there were also well-founded reasons to doubt, no age test was requested. Quite a few others have shown that the implementation of asylum policy results in substantive inequality before the law as well. At the level of nations, ${ }^{5}$ states (i.e., cantons) ${ }^{6}$ regions, ${ }^{7}$ asylum-seekers centres, ${ }^{8}$ and individual professionals, ${ }^{9}$ similar or even identical asylum applications have different outcomes. On the other hand, little is known about the causes of both forms of inequality. ${ }^{10}$ In other words, it is well known that the implementation of asylum policy results in both forms of inequality but it is hardly known what causes them. The goal of this study is to reveal some particular causes.

Explanations were sought in the working conditions of the decision employees, and in their personal characteristics. Explanations regarding the institutional context were not taken into account because data were only collected systematically at the level of the individual employees. The next section is about the hypotheses. Then follows section three about the collection of the data, the research design, the operationalization, and the analytic strategy. Section four is about the results, and the final section is about conclusions and recommendations.

\section{Theory and Hypotheses}

Procedural Inequality

According to Lipsky, ${ }^{11}$ officials- "street-level bureaucrats"are unable to do justice to the specific characteristics of individual cases because they are chronically plagued by a lack of time. In order to deal with the continuous flow of new cases, street-level bureaucrats often accept incomplete information and information that clients deliver themselves because the collecting of missing information and of information gathered independently of the interested party is usually difficult and time-consuming.

However, the fact that the shortage of time is inherent in the work of street-level bureaucrats does, of course, not imply that they all suffer of it to the same extent. Therefore, differences in work pressure could cause variation in the extent to which they are prepared to decide on the basis of incomplete or client-dependent information. There are indeed several indications that officials are more willing to accept the information that is present about a case as they are under more work pressure: time constraints encourage immigrant inspectors to rely on simplifying categories when questioning travellers ${ }^{12}$ and social workers take fewer cues into account when dealing with accusations of elder mistreatment as the caseload of the county in which they work is higher. ${ }^{13}$ So, the expectation is that officials who are responsible for the implementation of asylum policy are more willing to accept the obtainable information on an asylum application as they perceive more work pressure (hypothesis 1a). Furthermore, it can be expected that especially newer employees perceive a lot of work pressure (hypotheses $1 \mathrm{~b}$ ). Usually the most important task of officials is to make decisions on individual cases and since newer employees are still learning to do the job they may need more time to make a decision than experienced employees.

The second reason why officials might differ is the extent to which they take for granted the information that is present about a case refers to the quality of their reputation. When making actual decisions, employees take into account their experiences with previous cases-their so-called prior knowledge. ${ }^{14}$ This means that decisions about individual cases cannot be seen in isolation from the outcomes of previous ones: "Decision-makers, then, do not see and treat cases as self-contained, isolated entities, but rather as practical tasks embedded in known and foreseeable courses of institutional actions." 15 Administrators use their experience with the outcome of previous decisions in particular to protect their own reputation and that of their organization. ${ }^{16}$ This means that they try to gain recognition for their decisions and to prevent them from being overturned. Employees who have been successful in this respect in the past are expected to have the least problems with taking for granted the information that is available about a case. After all, they have received few signals that this has decreased the carefulness of their decisions. This means that it is to be expected that decision makers are more inclined to live with the available information on an asylum application as they have a better reputation (hypotheses 2).

\section{Substantive Inequality}

Differences in the extent to which caseworkers take for granted the disposable information on an application refers to procedural inequality. Those who decide not to take it for granted will eventually base their decisions on different data then those who do. After all, only the former decide to complement or verify the information on hand. Subsequently, how can these differences in their final decisions be explained?

Researchers often mention the importance of role definition. Most street-level bureaucrats are primarily responsible for the distribution of scarce resources to fulfill the needs of clients. Several researchers have demonstrated that this responsibility is related to role conflicts. Some emphasize the importance of controlling the distribution of scarce resources, while others give more priority to fulfilling the needs of clients. These two types of employees are often distinguished. 
For example, "hard-liners" are opposed to "soft-liners," 17 "gatekeepers" to "advocates," 18 and "bureaucrats" to "professionals." ${ }^{19}$ Among Canadian ${ }^{20}$ and British ${ }^{21}$ immigration officials one also finds "gatekeepers" and "facilitators," respectively "doves" and "hawks."

Researchers who mention role definition refer to at least one of the following five attitudes: preferring either a restrictive or lenient policy, defining a role as gatekeeper, defining a role as client advocate, doubting the integrity of clients, and, finally, formalism. The fact that role definition has different definitions suggests that this concept consists of a complex of related attitudes that provide a coherent vision-or "theory-in-use"22_about the preferred implementation of policy. The expectation is that "hard-liners" combine a preference for a restrictive policy with doubts about the integrity of clients, with a formalistic work attitude, and with giving high priority to their role as gatekeeper and low priority to their role of client advocate; while "soft-liners" take the opposite position in all respects. One question addressed in the present study was whether these five attitudes indeed form a coherent theory-in-use.

Although some researchers doubt that role definition really influences decisions, ${ }^{23}$ this has been demonstrated to be the case in many policy domains. Examples refer to disablement benefits, ${ }^{24}$ financial provisions on divorce, ${ }^{25}$, labour permits, ${ }^{26}$ provision of housing, ${ }^{27}$ and public assistance. ${ }^{28}$ Nagi suggests that the impact of individual attitudes on the implementation of policy is greater as the general public debate about the stinginess or open-handedness of service organizations increases. ${ }^{29}$ The more often personnel are confronted with contradictory social norms the more they are forced to depend upon their own convictions. If Nagi is right, then role definition should certainly have an effect on the implementation of asylum policy. The Dutch Immigration and Naturalization Service (IND) has been criticized frequently by both supporters and opponents of restricting asylum policy, with the result that its personnel think that they can never do the right thing in the eyes of the media, politicians, or pressure groups. ${ }^{30}$ Because of the contradictory demands of the social environment regarding the implementation of asylum policy, it is to be expected that the preference for a lenient asylum policy results in granting permits (hypothesis 3a).

However, it is not likely that role definition comes out of the clear blue sky. Decision makers not only do their job, but also take part in society more broadly as citizens. Moreover, they bring their professional background to their work. Both can influence their role definition. According to Stone, ${ }^{31}$ both a person's work experience and the nature of his or her profession $^{32}$ are relevant factors of professional background. Experienced co-workers, so-called "agency veterans," would be more cynical about clients than would newer employees, either because experience makes it easier to recognize cheating clients or because employees become frustrated about the limited possibilities that bureaucratic organizations generally offer to meet the needs of clients. In relation to the nature of one's profession, Stone contrasts people who work within the judicial system to caregivers. The former are more likely to have a negative attitude towards clients because they are regularly confronted with the darker side of human nature and because they are used to treating people as potential suspects. ${ }^{33}$ Caregivers usually have a positive attitude towards clients because in their work affective values such as helping and looking after people are stimulated. If men are indeed socialized through their profession, as Stone maintains, then this ought to have a lasting effect on their role definition. In other words, if caseworkers have worked within the judicial system or as caregivers of asylum seekers, then this should still be noticeable in their present role definition as caseworker. So, it is to be expected that inexperienced employees (hypothesis $3 \mathrm{~b}$ ), people without a professional history within the judicial system (hypothesis 3c), and decision makers who have worked as asylum-seeker aid workers (hypothesis 3d) are most in favour of a lenient asylum policy.

With respect to the influence of political convictions on role definition, Stone ${ }^{34}$ emphasizes the importance of conservatism and of fear of economic deterioration (status anxiety). Both would result in a negative attitude towards clients. Conservatives take a negative stand because they emphasize the importance of civil duties, while clients make an appeal to civil rights. ${ }^{35}$ Perceived economic threat causes a negative attitude because the status position of civil servants deteriorates in comparison to citizens who get help. Among the general population, fear of economic deterioration and conservatism also result in the preference for a restrictive immigration policy. ${ }^{36}$ People who are fearful of economic deterioration oppose immigration because they fear that this will deplete social services and will increase competition in the job market. In the case of conservatism, it is the conviction that the lack of commonly held norms and values undermines social cohesion. Because of this, it is to be expected that conservatism (hypothesis 3e) and perceived economic threat (hypothesis 3f) lead to disapproval of a lenient asylum policy.

Finally, substantive inequality might be caused by the reputation of the decision maker. A predictable hypothesis is that employees get more freedom of choice as their reputation is better. This would mean that the personal attitude towards the carrying out of asylum policy has more effect on the eventual decision as the reputation of the caseworker is better (hypothesis 4a). Next, there are indications that the influence of the reputation depends on the context. For example, Scott did an experiment in which he asked students to take 
the role of a caseworker and to make a decision on a request for public assistance. ${ }^{37}$ Contrary to his expectation students who were told that a superior would check their decisions did not make more consistent decisions than those who were not told so but simply refused more often. According to Scott the reason for this was that the students only had to account for their positive decisions. The certitude that only grants of public assistance were scrutinized by superiors encouraged respondents to refuse public assistance. Fleurke and de Vries ${ }^{38}$ showed that, under other conditions, the wish to protect one's own reputation can inversely also lead to granting. This would be especially likely to occur when the clients of streetlevel bureaucracies are organized well. In this case, officials run the risk that their refusals will be attacked. These findings indicate that officials accommodate their decisions with the risks involved for themselves. Those who have a reputation for being too restrictive especially run a risk when they refuse, while the reverse is true for the employees who are known for their leniency. This leads to the expectation that caseworkers grant a permit more often as their reputation for being too restrictive is stronger, while the reverse is true for those with a reputation for being too lenient (hypothesis $4 \mathrm{~b}$ ).

\section{Data, Research Design, Operationalization, and Analytic Strategy \\ Data}

During the collection of the data in the fall of 2002, the implementation of asylum policy was spread over five regions of the Netherlands and, within the regions, over one or more units. Selections have been made at both levels. Originally, the intent was to restrict the project at the regional level to the Northwest and the Central regions. The reason for this was that previous research had shown that these were the most restrictive and the most lenient respectively. ${ }^{39}$ Later, the Southwest region was also included because the IND wanted to spread the burden of the research more evenly within the organization. At the unit level, selection took place solely in the Central region because the Northwest and the Southwest each had only one asylum unit. Three out of five asylum units were selected in the Central region. One unit offered to participate of its own volition; the others did so at my request. I did not know anything about the units beforehand. Everybody within the units was asked to participate except for the unit managers and the people who were still learning to do the job. Ninety-eight decision makers co-operated and the response rate was 94.2 per cent.

\section{Research design}

All ninety-eight respondents were presented the same fictitious asylum application with the request to prepare a decision on the permit for temporary residence as asylum seeker (henceforth: asylum permit) and on the permit for residence as unaccompanied minor immigrant (henceforth: permit for minors). An interview followed shortly after, during which respondents were asked to explain their decisions. During the interview, supplementary information about the application was presented and respondents were again asked to make both decisions. In addition, respondents handed in a questionnaire that they completed beforehand. Transcriptions of the interviews were made and, after coding the decisions, they were connected to the survey data. In an accompanying letter, which was also explained orally, respondents were urgently asked not to deliberate with anybody about the case, but instead to prepare it individually. This was done to make sure that the decisions not only referred to an identical case but were also made under identical circumstances.

However, there were two disadvantages attached to this procedure. They had to do with the possibility of generalizing the findings to actual implementation practice. First, respondents were not allowed to deliberate about the case with others, while in practice deliberation is an essential element of their work. This means that decisions are normally taken in a less individual fashion than in the present case. In addition, decisions are usually controlled. This means that mistakes can be corrected. However, it is not likely that these limitations have had a huge impact on the findings. Specifically, to the question whether internal control would have led to other decisions, only 2.5 per cent answered affirmatively and 10 per cent did not preclude this. The great majority thought that this would not have led to other decisions.

Another disadvantage of the research procedure was that respondents knew that their decisions were based upon a fictitious case. The effect of this may have been that some decision makers did not prepare themselves as thoroughly on the fictitious case as they would have done on a real application. The first thing that was done to limit this negative consequence was to limit the preparation time as much as possible. This was done by presenting just one application, hence, a short one. Secondly, an attempt was made to make the application as realistic as possible, so that the respondents would "forget" they were preparing a fictitious case. For example, the application was printed on paper with the logo of the Ministry of Justice, and as many standard phrases as possible were used. Also, real events and situations were processed in the application. Information was gathered from official messages, newspaper articles, and files of real asylum applications. Apparently, this succeeded well, because, when the interview was over, several respondents asked whether it concerned a "real" application, although the accompanying letter stated that the case was fictitious. 
If it was so important to present a realistic application, why then was an existing one not used? I wanted to keep the chance on differing decisions in my own hands. I artificially increased the chance of finding differing decisions by increasing the number of decisions that had to be made on the application and by focusing the application on parts of the asylum policy that contain room for discretion. ${ }^{40}$ These two strategies were effectuated in four ways.

Firstly, the application focused on an unaccompanied asylum seeker who was older than sixteen on his arrival in the Netherlands, but was evidently younger than eighteen at the moment of data collection. Caseworkers have to test whether minors that are not eligible for an asylum permit are eligible for a permit for minors. This means that two decisions must be made with minor asylum seekers and just one with adults. However, the official test for minors is regulated in great detail and substantial room for discretion exists only with respect to applicants who fall within the category chosen here. With respect to this category, it has to be determined whether the person concerned is unaccompanied, independent, and if not, whether there are possibilities for reception in the country of origin. These three tests all offer possibilities for differences in interpretation.

The second way was by building an extra phase into the research procedure. Respondents were asked to make decisions not only after reading both interview reports, but also after reading the corrections and amendments to the reports. The total number of decision proposals came down to four because of the extra phase (the decision on the asylum permit and permit for minors in the first and second phase).

Thirdly, Chechnya was chosen as the region of origin. This federal republic is one of the few areas that is officially considered unsafe, but to which categorical protection policy no longer applies. When a country has officially been declared safe, asylum permits are rarely granted, while if a country applies for categorical protection, an asylum permit is automatically granted unless contraindications are present or the identity or nationality of the applicant is doubted. So, Chechnya is a region of origin that offers room for both grants and refusals. The fact that it is official policy to refuse refugees from Chechnya because they have a flight alternative somewhere else in the Russian Federation is not an insurmountable problem. This policy cannot be applied automatically because it is also stated officially that people with a Caucasian appearance can run into discrimination and, consequently, may be granted an asylum permit.

The last way is by focusing the application on trauma policy. This policy was revised profoundly with the introduction of the Asylum Act 2000 and had not yet taken its definite shape in every aspect. Because the many questions caseworkers posed to the policy departments about the man- ner in which the trauma policy should be applied to specific cases, complementary policy was made in the form of answers to questions, memos, and a guideline. Furthermore, symposia were organized to explain this policy and a more elaborate version of it was in the pipeline (in the form of a so-called Intermediate Aliens Circular Message (TBV)). In the application, events were described to which concepts of the trauma policy like "severe abuse," "non-criminal detention," and "cause of departure" applied and which were often unclear to the personnel.

\section{Operationalization}

Two models were tested. The first dealt with the explanation of procedural inequality (whether or not to take for granted the information provided on the application) and the second with the substantive inequality (refusing versus granting).

Taking for granted the information available about the asylum application was measured on the bases of the decisions proposed on the fictitious case. With respect to both the asylum permit and the permit for minors one could choose between not taking for granted the available information (i.e., postponing the decisions to complement or to verify this information) and taking it for granted (i.e., refusing or granting permits). People were first asked to choose after reading an interview report about the nationality, identity, and journey of the applicant and one about his motives for fleeing (phase one) and then again after reading corrections and amendments to both reports (phase two). Table 1 shows that the decisions of the caseworkers differ a lot. The four decisions were combined after a reliability test proved that this would result in an internally consistent measurement instrument $(\alpha=0.70)$. The factor loadings of the four decisions to either take the available information for granted or not are respectively: asylum permit first phase (0.61), permit for minors first phase (0.82), asylum permit second phase (0.59), permit for minors second phase $(0.87)$. The compounding of the four decisions resulted in five categories that increasingly indicate an acceptance of taking the available information for granted: (i) postponing all four (18.4\%); (ii) postponing three (3.1\%); (iii) postponing two (29.6\%); (iv) postponing one (26.5\%); (v) postponing none of the four decisions $(22.4 \%)$.

Perceived work pressure consists of a scale that is made up of five items with "no" and "yes" as answering categories. This scale was taken from Jetten and Pat. ${ }^{41}$ This scale is internally consistent ( $\alpha=0.76$, see Appendix 1, Table 2). A high score means a lot of perceived work pressure. ${ }^{42}$

The reputation of the decision maker was measured with the help of six indicators for both positive and negative feedback on previous decisions. Positive feedback was measured with the number of compliments that respondents had received since the introduction of the Aliens Act 2000 for grants 
Table 1. Decisions on the asylum application (Frequencies, percentages, $\mathrm{N}=98$ ).

\begin{tabular}{|l|r|r|r|r||}
\hline & \multicolumn{2}{|c|}{ After reading the reports } & \multicolumn{2}{c|}{$\begin{array}{c}\text { After reading corrections and } \\
\text { amendments }\end{array}$} \\
\hline & Asylum permit & $\begin{array}{c}\text { Permit for } \\
\text { minors }\end{array}$ & Asylum permit & $\begin{array}{c}\text { Permit for } \\
\text { minors }\end{array}$ \\
\hline No & 38.8 & 54.1 & 8.2 & 51.0 \\
\hline Maybe & 48.0 & 29.6 & 66.3 & 33.7 \\
\hline Yes & 13.3 & 16.3 & 25.5 & 15.3 \\
\hline
\end{tabular}

and refusals respectively. The percentage of compliments for grants and refusals respectively is distributed as follows: (i) zero times $(79.8 ; 81.1)$; (ii) one time $(7.4 ; 3.2)$; (iii) two times $(7.4 ; 2.1)$; (iv) three to five times $(3.2 ; 7.4)$; (v) more than five times $(2.0 ; 6.3)$. Negative feedback was measured in the first place on the basis of the number of times that an employee had to revise a decision under pressure from colleagues or superiors since the implementation of the Aliens Act 2000. This can either refer to the number of times that one granted under pressure from colleagues when one wanted to refuse originally, or to the number of times that one wanted to grant in first instance but eventually refused. The answers to both questions are distributed as follows: (i) zero times (41.8; $58.2)$; (ii) one time $(30.6 ; 20.4)$; (iii) two times $(19.4 ; 15.3)$; (iv) more than two times $(8.2 ; 6.1)$. Furthermore, negative feedback was measured on the basis of the outcome of appeals made by asylum seekers against refusals by the IND. This refers to the proportion of appeals granted by the IND and by the appellate court that decision makers knew of personally. ${ }^{43}$

The more compliments employees received, the less often they had to reverse decisions under pressure from colleagues or superiors; and the less often they were confronted with appeals granted by the IND and by the appellate court, the better their reputation. So, these six indicators were added up, after multiplying the scores for negative feedback by minus one, and after standardizing the scores. A high score indicates a good reputation.

Experience distinguished less experienced employees who were not authorized to sign decisions (46.9 per cent) from experienced employees who were authorized to do so (53.1 per cent).

Granting was measured on the basis of the four decisions proposed by the respondents with respect to the application. One could choose between refusing, postponing, and granting the asylum permit and the permit for minors in first and second instance. Postponing can eventually result in either a refusal or a grant and is therefore defined as the middle category. An internally consistent scale was constructed by combining these four decisions $(\alpha=0.73)$. Their factor load- ings were as follows: asylum permit first phase (0.57); permit for minors first phase (0.90); asylum permit second phase (0.56); permit for minors second phase (0.89). The scale consists of the following nine categories, indicating increasingly the decision to grant permits. This variable is distributed as follows: (i) (7.1\%); (ii) (16.3\%); (iii) (21.4\%); (iv) (7.1\%); (v) (27.6\%); (vi) (4.1\%); (vii) (11.2\%); (viii) (1.0\%); (ix) (4.1\%).

The preference for a lenient asylum policy consists of the combination of the five following attitudes: preference for the further restriction of asylum policy, role definition as gatekeeper, role definition as advocate, distrust in the credibility of asylum seekers, and formalism (see above). The internal consistency of the scales measuring these attitudes ranged from sufficient to good, with the exception of formalism (see Appendix 1, Table 3). The formalism scale was nonetheless used in the analysis because of the high factor loadings of all items.

Principal component analysis with the five scales resulted in one factor with an Eigenvalue of more than 1. This factor explains 50 per cent of the total variance. This shows that the five attitudes that are used alternately in the literature for the operationalization of role definition indeed correlate strongly, as expected. The factor loadings are: for the preference of a restrictive asylum policy -0.87 ; for role definition as gatekeeper, -0.74 ; for role definition as advocate, 0.65 ; for distrust in the credibility of asylum seekers, -0.73 ; and for formalism, -0.48 . The attitudes with negative factor loadings were multiplied by minus 1 , so that a high score indicates a preference for a lenient asylum policy.

Reputation for being too restrictive has to do with the extent to which employees, according to others, refuse too often and do not grant often enough. This was measured with the help of the same six indicators that were used to measure the reputation for being a good decision maker (for the scores on these six items, see the operationalization of the latter variable). These items were however categorized differently. Based on the presupposition that compliments are meant to stimulate manifested behaviour, this implies that the number of compliments for grants indicates a reputation for being too restrictive, while the reverse is true for refusals. The 
number of times that an employee granted under pressure from colleagues when one wanted to refuse originally indicates a reputation for being too restrictive, while the reverse is true for the number of times that one wanted to grant in first instance but eventually refused. The number of granted appeals or granted courts of appeal employees recalled by employees indicates a reputation for being too restrictive. These six indicators were added up after multiplying the number of compliments for refusals and of the number of refusals under pressure from others by minus one, and after standardizing the scores. A high score indicates a reputation for being too restrictive.

The reputation of the decision maker multiplied by the preference for a lenient asylum policy is an interaction term that is incorporated in the model to see whether caseworkers accommodate their decisions to a larger extent to their role definition as they have a better reputation (hypothesis $4 a$ ).

Professional past within the judicial system was considered; 6.1 per cent have worked in the past in the judicial system as (fraud) investigator or policy officer, and 93.9 per cent have not.

Former asylum-seeker aid workers included 15.3 per cent who have helped asylum seekers either as volunteers or professionals, and 84.7 per cent who have not.

Conservatism has to do with the rejection of cultural differences. This variable consists of the combination of authoritarianism, distrust in human nature, political party preference, and multiculturalism. "Authoritarianism" expresses the conviction that individuals should conform to formal rules and official authorities because otherwise they will admit to their destructive primal instincts and impulses. This was measured with the help of eight items, which are part of the F-scale for authoritarianism of Adorno et al. ${ }^{44}$ or of research that is based upon it, and produces an internally consistent scale $(\alpha=0.71$, see Appendix 1, Table 4). This aversion to deviant behaviour implies simultaneously a distrust in human nature and, as research has demonstrated, a preference for right-wing parties. ${ }^{45}$ Political party preference is measured on the basis of the question on which party one would vote for if there were elections for Parliament. The answers were categorized in ascending order with respect to conservatism: (i) Green Left Party, Socialist Party, or considering either the Green Left Party and the Social Democratic Party (34.6); (ii) Social Democratic Party or Democratic Party (32.6); (iii) Republican Party, Christian Democratic Party, Christian Union, doubters, and non-voters (32.6). ${ }^{46}$ Distrust in human nature is measured independently with the help of Wrightsman's "Philosophy of human nature" scale $(\alpha=0.77) .{ }^{47}$ "Multiculturalism" consists of the conviction that foreigners are an improvement for society instead of a threat. This scale is also internally consistent ( $\alpha=0.73$, see Appendix 1, Table 4$)$.
Principal Component Analysis with all four measures resulted in one factor with an Eigenvalue of 2.0. This factor explains 51.1 per cent of the total variance. The factor loadings of the different components are as follows: authoritarianism, 0.77 ; political party preference, 0.54 ; distrust in human nature, 0.68 ; and multiculturalism, -0.86 . The score for multiculturalism was multiplied by minus 1 , so that a high score indicates conservatism.

Perceived economic threat concerns the estimation of the actual level of welfare and of the expected decrease of welfare in the future. This attitude was measured with the help of eight Likert items used previously in the survey "Cultural changes in the Netherlands 1992" (see Appendix 1, Table 5). ${ }^{48}$ The scale for perceived economic threat is sufficiently internally consistent $(\alpha=0.67)$.

\section{Analytic Strategy}

The hypotheses were tested by way of bivariate correlations and multiple regressions. For reasons of readability two figures will be presented in the main text of the following section that only depict the significant beta coefficients generated by the linear regressions (method "enter," weight estimates "ordinary least squares"). More complete and detailed results are presented in Appendix 2, Tables 6 and 7. Both tables show that the mutual correlations between the independent and intermediate variables did not have an unusually large effect on the results and did not cause problems with multicollinearity. Both tables show that correlations between the independent and intermediate variables did not have a distorting effect on the results. This can be deduced from the fact that the correlations and beta coefficients of the three models tested resemble each other with respect to direction and strength. Moreover, test results incorporated in both tables demonstrate that multicollinearity has not influenced the reliability of the results negatively. As a rule of thumb, "variance inflation factors" (VIF) of more than 10 indicate problems with multicollinearity. ${ }^{49}$ The value of all explaining variables is below 2.5. In short: the results shown in Appendix 2 make clear that the results depicted in both figures to follow are robust and consistent.

\section{Findings}

\section{Procedural Inequality}

The explanation of the extent to which decision makers take the information that is available on the asylum application for granted is depicted in Figure 1. It shows that the more work pressure employees perceive the more willing they are to take this information for granted. In correspondence with hypothesis 1a it is true that employees are less willing to spend time and energy to complementing or verify information about an asylum application as they perceive more work pressure. 
Figure 1. Explanation of the extent to which decision makers take the information that is available on an asylum application for granted based on perceived work pressure, reputation, and experience (Betas, $\mathrm{N}=97$ ).

\begin{tabular}{|l|}
\hline $\begin{array}{l}\text { Experienced } \\
\text { employees }\end{array}$ \\
\hline
\end{tabular}

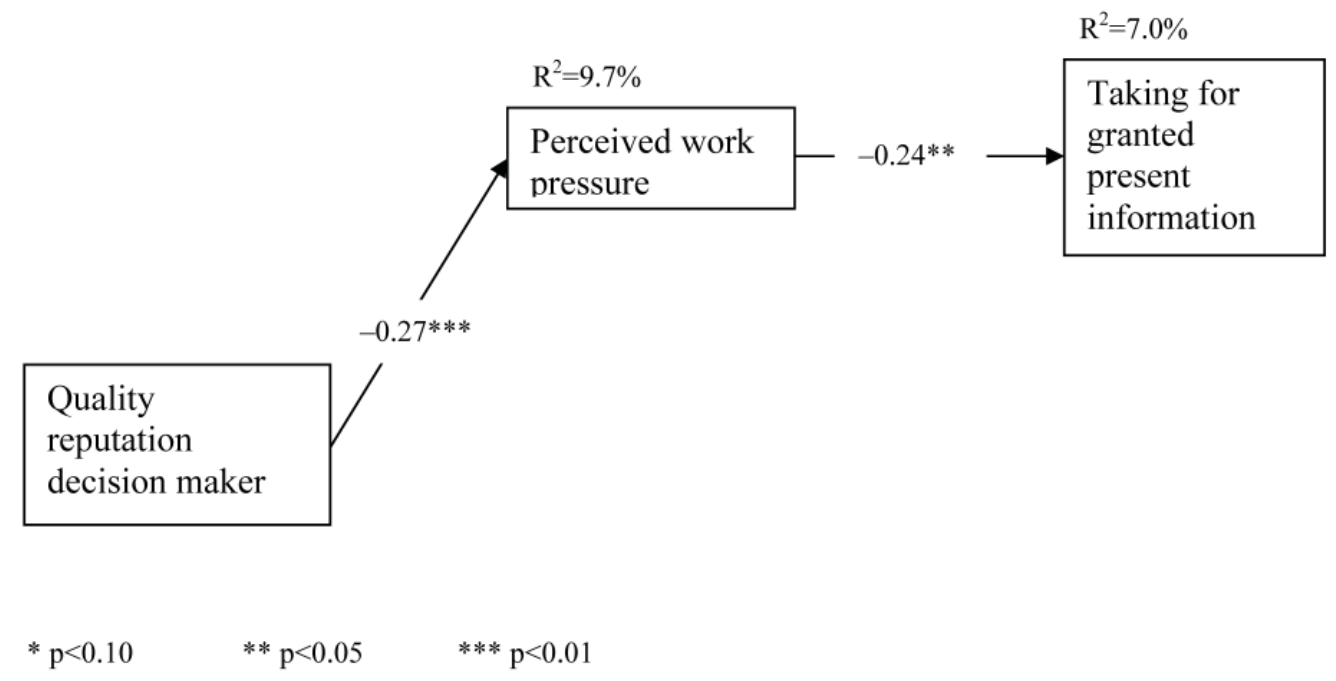

However, hypothesis $1 \mathrm{~b}$ was rejected. Experienced workers do indeed perceive less work pressure than do those with less experience $(\beta=-0.16)$, but this effect is (just) not significant $(\mathrm{p}=0.10)$. A possible explanation for this is that experienced employees have more tasks and responsibilities than the less experienced. In fact, an extra task that the experienced workers have is the checking of the work of their less experienced colleagues. Thus, it is possible that experience decreases work pressure, but that this is compensated for by the fact that it leads to new tasks and responsibilities.

Hypothesis 2 was also rejected. Employees are indeed more willing to take the available information for granted as their reputation is better $(\beta=0.17)$, but this effect is (just) not significant $(\mathrm{p}=0.11)$. Indirectly, a good reputation has a reverse effect. After all, the perceived work pressure that increases the chance of taking the available information for granted is least among the employees with the best reputations. This is understandable because employees need less time to process the criticism they receive on their decisions as their reputation is better. This leaves caseworkers with the best reputations the most time to test the uncorroborated presuppositions about the eligibility of the application or to verify the information that the interested asylum seeker has provided. This difference can occur because the caseload of the caseworkers is not adapted to the amount of feedback they receive on their decisions. So, an unintended conse- quence of feedback is that employees are more inclined to take for granted the information that is obtainable on an asylum application because it takes time to process it.

Experience, reputation, and work pressure explain seven per cent of the total variance of taking for granted the ready information on an asylum application.

\section{Substantive Inequality}

Figure 2 depicts the explanation of the differences in final decisions. It shows that supporters of a lenient asylum policy grant most often. This corresponds with hypothesis $3 \mathrm{a}$. The preference for a lenient asylum policy is greatest among employees with a past as asylum-seeker aid worker and among liberal employees. These findings confirm hypotheses $3 \mathrm{~d}$ and 3e. This means that the personal preference for the implementation of asylum policy has an effect on the outcome of the asylum decision and that role definition is dependent on the political and professional background of the caseworker.

Hence, hypotheses $3 \mathrm{~b}, 3 \mathrm{c}$, and $3 \mathrm{f}$ were rejected. Contrary to hypothesis $3 \mathrm{~b}$, experienced workers do not oppose a lenient asylum policy more than inexperienced ones. In other words, people with much experience are not more negative and cynical towards asylum seekers than people with little experience. The absence of this difference might be explained by the fast turnover of personnel within the IND. It is plausible that especially highly motivated people stay the 
Figure 2. Explanation of differences in deciding to grant a permit based on role definition, quality and kind of reputation, and background characteristics (Betas, $\mathrm{N}=97$ ).

$$
\begin{aligned}
& \text { Experienced } \\
& \text { employees }
\end{aligned}
$$

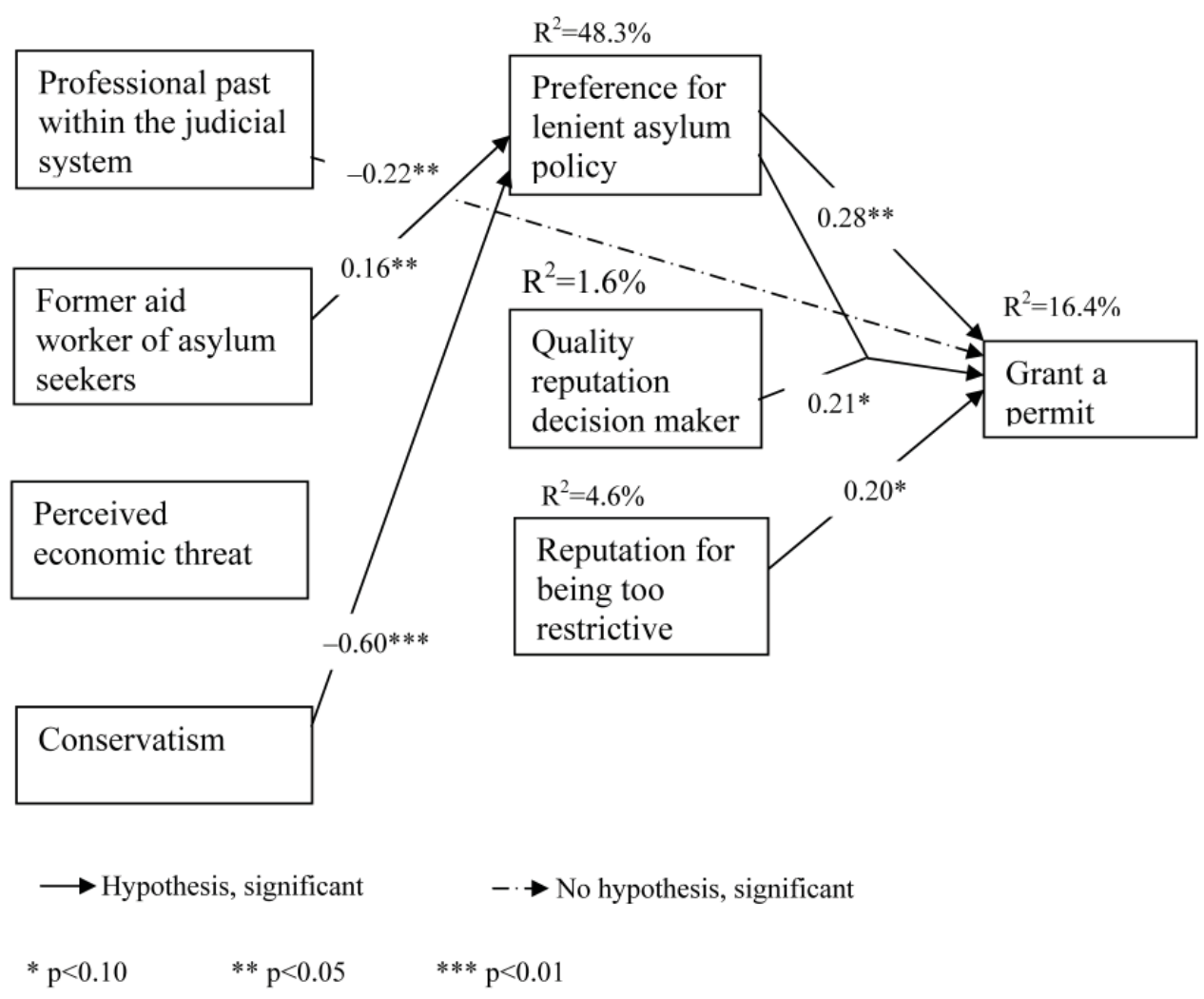

longest and that those who become cynical because of the stories "they have heard so often already" leave the organization quickly. So, it is possible that experience does lead to role definition as "hard-liner," as was expected, but that this influence is invisible in organizations with a high turnover, because of the self-selection of employees.

Hypothesis $3 \mathrm{c}$ was rejected because a professional past within the judicial system leads to refusing independently of role definition, while it was predicted that this would be so because of an aversion to a lenient asylum policy. Even now that this is known, it is not easy to understand why it is so, for this direct effect can not have anything to do with the fact that these people have become more distrustful towards asylum seekers because this is an element of role definition.

Contrary to hypothesis $3 \mathrm{f}$, fear for economic deterioration does not lead to favouring a lenient asylum policy. Although the negative correlation between both attitudes is considerable ( $\mathrm{r}=-0.27 ; \mathrm{p}<0.01$; not depicted in Figure 2),

this effect completely disappears when controlling for conservatism. This means opposition to a lenient asylum policy is entirely caused by the fact that there are many conservatives among the employees who perceive much economic threat. Perceived economic threat does have an independent effect on the rejection of a lenient asylum policy among the general public, ${ }^{50}$ although the effect of conservatism and negative stereotyping of foreigners is much stronger. Hence economic motivations do not have an effect on either the racism of pupils ${ }^{51}$ or on negative attitudes towards ethnic minorities, ${ }^{52}$ while opposing cultural differences do have these effects. This means, in fact, that the rejection of hypothesis $3 \mathrm{f}$ in combination with the affirmation of hypothesis $3 \mathrm{e}$ underlines that the attitude toward cultural differences determines negative attitudes towards aliens to a greater extent than economic motives.

Next, hypotheses $4 \mathrm{a}$ and $4 \mathrm{~b}$, with respect to the influence of the reputation on the final decisions, are affirmed. Attitude 
towards the implementation of asylum policy has a greater impact on the outcome of the decisions made as the reputation of the employee is better. This means that caseworkers get more discretion to decide as they please, as their reputation is better. The sort of reputation also has an effect on the final decision. Employees who are known to be too restrictive grant most often, while the reverse is true for the employees with a reputation for being too open-handed. This means that employees accommodate their actual decisions to the feedback that they got on previous decisions. In other words, this feedback restrains them from deviating too much from dominating decision norms. However, both effects are not very strong. The operationalization of the reputation of the decision makers possibly shows why not. It shows that decision makers do not get much feedback on their previous decisions: they rarely revise their decisions under pressure from colleagues or superiors, they receive even fewer compliments on their decisions, and it is really exceptional that they are aware of the outcome of appeals made against their own decisions. So, one can assume that the influence of the reputation on the outcome of decisions increases as the feedback is intensified.

Altogether, role definition, professional background, political attitudes, and reputation explain over 16 per cent of the total variance in the decisions to grant permits.

\section{Complementary Explanation}

The qualitative interviews about the case exposed yet another cause of substantive inequality. This is the application of semi-official policy such as memos and policy guidelines. The next example is about the application of internal memos. Several people working in the Central region refused an asylum permit based on the trauma policy because they thought that the applicant did not meet the criteria for serious abuse enumerated in an internal memo. The criteria were that the person in question had to have undergone treatment by a physician and had to have been unable to work or to function normally for at least six weeks. This memo did not exist in the other regions and, consequently, many caseworkers in the other regions granted an asylum permit because of the abuses the applicant had undergone during his detention.

The second example shows that also the answers of policy departments to questions asked by individual employees about the way sections of the policy should be applied to specific cases lead to substantive inequality. An employee decided to grant an asylum permit based on trauma policy because of the answer of a policy department to a question of hers. She had asked whether traumatizing events that take place during the flight could ever lead to a permit. The national policy department answered that this is possible. She then granted an asylum permit because, in the file of the ap- plicant, it was written that he was forced through a minefield during his flight. However, the majority did not even consider this event because they assumed that traumatizing events could only result in a permit when they were the direct motive to flee.

There are two reasons why not everybody conforms to the answers of policy departments. The first is because usually only one or two people know of an answer. Answers are not fed back systematically. Secondly, employees tend to consider the answers more as advice than as coercive guidelines. This can be explained by the fact that according to the caseworkers the answers are frequently ambiguous or contradictory. Consequently, they feel more or less free to choose whether or not to act in line with the answer.

In short, in addition to the personal characteristics of the decision makers, the selective application of semi-official policy also causes inequality in the execution of asylum policy.

\section{Conclusions and Recommendations}

This research demonstrated that the implementation of asylum policy is accompanied with procedural and substantive inequality. Some decision makers decide to postpone decisions to complement or verify the information that is available on an asylum application, while others take this information for granted. Hence, some decision makers grant a permit on this application while others refuse it. In itself these findings prove little about the extent of both forms of inequality in the implementation of asylum policy because the case that was presented to the decision makers was deliberately constructed to maximize the chance of differing decisions. However, in combination with the studies cited in the introduction these findings indicate that both forms of inequality are no exception.

Current study also showed that the working conditions and the characteristics of individual employees cause both forms of inequality. Procedural inequality is caused by perceived work pressure. In particular, employees who perceive much work pressure decide to take the information that is available on an application for granted, and work pressure is highest among employees with the worst reputations. The latter need the most time to process criticism on their previous decisions so they have the least time left for complementing and verifying information on asylum applications. Substantive inequality is caused by the attitude, background, and reputation of caseworkers. Supporters of a lenient asylum policy grant residence permits most often. This role definition is most common among employees who have worked as asylum-seeker aid workers and among liberals. Employees with a professional past within the judicial system are most inclined to refuse permits independent of their role defin- 
ition. Hence, role definition has more effect on the final decision, as the reputation of a decision maker is better. This means that employees get more discretion to decide as they please, as their reputation is better. Employees are also more likely to grant a permit as their reputation for being a too restrictive decision maker is stronger. This means that feedback prevents employees from deviating too much from the dominant decision norms. Finally, substantive inequality depends also on semi-official policy guidelines that are location specific and that are applied selectively.

So the implementation of asylum policy results in systematic differences. One could dispute the societal importance of this conclusion by reasoning that the decisions of the IND employees are not final: asylum seekers can appeal negative decisions in court. However, the appeal procedure does not guarantee unambiguous outcomes. After all, it has occurred, for example, that trial judges base their own decisions on previous ones. They are more likely to sentence when they have read the charges before the trial, than when they have not. ${ }^{53}$ The reason for this is that in countries like Germany and the Netherlands the charges do not contain the demurrer of the defendant. And although files of asylum applications do contain the point of view of the asylum seeker, the communication within the asylum procedure usually has a negative effect on the representation of asylum seekers. ${ }^{54}$ Hence, trial judges, as well as immigration officials, ${ }^{55}$ are not only inclined to stick to previous decisions because they base their decisions on selective information but also because this is most efficient. This is what Lipsky ${ }^{56}$ called "rubber-stamping." On the basis of these findings, it is to be expected that judges are also inclined to go along with the decisions of the IND, as Spijkerboer ${ }^{57}$ has argued with respect to the Dutch High Court. And, indeed, research has demonstrated that appeals do not decrease regional differences in the execution of asylum policy in the Netherlands. ${ }^{58}$ So, it is not at all sure that systematic differences dissolve because of the right to make an appeal in court.

This means that it is logical to try to cancel out the causes of procedural and substantive inequality at the source. Which points of departure do the findings of this study offer to achieve this? Recruiting and selecting can help to establish a balanced staff with respect to role definition, political attitudes, and professional background. However, the best possibility to advance the unequivocal implementation of asylum policy is probably by intensifying feedback on decisions. After all, the limited amount of feedback that decision makers receive already decreases the impact of their role definition on decisions and causes them to conform to the dominant decision norms. These effects can be enlarged by complimenting caseworkers more often, making them revise their decisions more often if internal control gives rise to this, and confronting them sys- tematically with the outcome of appeals made against their own decisions. It would also help if the answers given by policy departments to questions about the way policy sections should be applied in specific cases were fed back systematically and if it would be made clear what the status of these answers is.

However, if the intensification of feedback were not combined with measures to decrease work pressure, then it would result in less careful decisions. After all, such feedback would be at the expense of the time that employees have left to complement and verify the information that is available on an asylum application. First of all, work pressure can be diminished by stopping early the slimming down of the IND because of the decreasing influx of asylum seekers since 2000. ${ }^{59}$ Another possibility is to reverse the sharp increase in the percentage of applications that is decided on in the fast-track procedure instead of the normal procedure. Nowadays manifestly unfounded claims and claims deemed not to require "timeconsuming investigation" enter the fast-track procedure. However, as a result of the vagueness of the parameters defining who should enter this procedure, in combination with the emphasis put on efficiency in the present political climate, applications are included in the fast track that do not belong there. ${ }^{60}$ And because these applications have to be decided on within forty-eight working hours, this implies that caseworkers have insufficient time to investigate the eligibility of these applications and that the asylum seekers have insufficient time to prepare themselves for the interviews and to collect evidence to substantiate their claims. The tightening of the criteria to include applications in the fast track can help to prevent decisions being made on the basis of uncorroborated presuppositions and unverified information because they are made under too much work pressure.

In any case, the recommendations are no plea against discretion as such. Asylum policy cannot possibly anticipate all unique characteristics of individual asylum applications while these characteristics can definitely be relevant for the eligibility of the applications. Therefore, it is desirable to give decision makers the freedom to take into account these unique factors when making decisions. What has to be prevented, though, is that identical applications are decided upon differently because of the use of discretion, because "where workers' discretion leads to unfair and unequal treatment of clients, with no compensation benefits, it should be desirable to reform systems by removing this unredeemed source of unfairness." 61 This certainly applies to the execution of asylum policy that can have huge consequences for the people involved. 


\section{Appendix 1 \\ Factor and reliability analyses measurement instruments}

Table 2. Factor and reliability analysis of perceived work pressure (Percentages, factor loadings, and Cronbachs alpha).

\begin{tabular}{|l|c|c|}
\hline \hline & \% yes & FI \\
\hline Do you have to work fast? & 32.7 & 0.82 \\
Do you have to do a lot of work? & 43.8 & 0.70 \\
Would you like to calm down in your work? & 73.5 & 0.82 \\
Do you generally have enough time to finish your work? & 83.7 & -0.54 \\
Do you work under time pressure? & 52.6 & 0.67 \\
\hline Cronbachs alpha & & 0.76 \\
\hline
\end{tabular}

Table 3. Factor and reliability analysis of the preference for a lenient asylum policy (Percentages, first and second-order factor loadings, and Cronbachs alphas).

\begin{tabular}{|c|c|c|}
\hline & $\begin{array}{l}\text { \% agree } \\
\text { (strongly) }\end{array}$ & FI \\
\hline \multicolumn{3}{|l|}{ Support for a restrictive asylum policy } \\
\hline The asylum procedure in our country attracts newcomers. & 10.4 & 0.66 \\
\hline A restrictive asylum policy is in the interest of genuine refugees. & 63.2 & 0.62 \\
\hline The High Court is too much on the side of the IND. & 4.2 & -0.50 \\
\hline The benefit of the doubt should be applied more often. & 21.7 & -0.47 \\
\hline Too many asylum seekers who are not eligible obtain a residence permit. & 27.7 & 0.79 \\
\hline The Dutch government should do more to deter asylum seekers from coming to our country. & 16.6 & 0.69 \\
\hline Cronbachs alpha & & 0.74 \\
\hline Second-order factor loading & & -0.87 \\
\hline \multicolumn{3}{|l|}{ Distrust of the credibility of asylum seekers } \\
\hline $\begin{array}{l}\text { Solicitors ascribe contradictions in interview reports too easily to cultural differences, lan- } \\
\text { guage problems, or the bad health of the asylum seeker. }\end{array}$ & 43.9 & 0.56 \\
\hline Many inconsistencies in reports of asylum seekers are caused by communication problems. & 18.3 & -0.55 \\
\hline Asylum seekers know exactly what to say to get a residence permit. & 29.6 & 0.53 \\
\hline Asylum seekers exaggerate their problems during interviews. & 47.4 & 0.57 \\
\hline Legal aid represents the interests of asylum seekers too one-sidedly. & 20.7 & 0.70 \\
\hline The asylum policy forces asylum seekers more or less to lie about documents and journey. & 20.4 & -0.51 \\
\hline $\begin{array}{l}\text { Asylum seekers who bring to the fore essential information later on in the procedure usually } \\
\text { have good reasons to do so. }\end{array}$ & 9.2 & -0.69 \\
\hline Cronbachs alpha & & 0.68 \\
\hline Second-order factor loading & & -0.73 \\
\hline
\end{tabular}

Table 3 (cont'd) 


\begin{tabular}{|c|c|c|}
\hline & $\begin{array}{l}\text { \% agree } \\
\text { (strongly) }\end{array}$ & FI \\
\hline \multicolumn{3}{|l|}{ Defining role as gatekeeper } \\
\hline If the IND did not exist, then the Netherlands would be flooded with immigrants. & 37.2 & 0.42 \\
\hline $\begin{array}{l}\text { If we apply the rules leniently, the housing of asylum seekers would quickly become un- } \\
\text { affordable. }\end{array}$ & 44.3 & 0.79 \\
\hline $\begin{array}{l}\text { Politicians have denied for too long that the Netherlands is too small and too full to afford an } \\
\text { open-handed asylum policy. }\end{array}$ & 22.7 & 0.72 \\
\hline $\begin{array}{l}\text { A restrictive asylum policy is necessary to take the pressure off the spending of public } \\
\text { money. }\end{array}$ & 36.7 & 0.75 \\
\hline The economic value of asylum seekers should never play a role in the asylum policy. & 74.5 & -0.39 \\
\hline $\begin{array}{l}\text { A lenient immigration policy results in a situation in which social services like unemployment } \\
\text { benefits and rent subsidy become unaffordable. }\end{array}$ & 16.5 & 0.87 \\
\hline Cronbachs alpha & & 0.74 \\
\hline Second-order factor loading & & -0.74 \\
\hline \multicolumn{3}{|l|}{ Formalism } \\
\hline $\begin{array}{l}\text { There ought to be a possibility for employees to refuse to agree to decisions they are princi- } \\
\text { pally opposed to. }\end{array}$ & 68.0 & -0.41 \\
\hline The intent of the law is more important than the letter of the law. & 55.8 & -0.72 \\
\hline A personal interpretation of the rules is not necessarily wrong. & 43.9 & -0.61 \\
\hline $\begin{array}{l}\text { The only possibility of taking a good decision is to imagine the person behind the asylum } \\
\text { seeker. }\end{array}$ & 78.6 & -0.55 \\
\hline The literal application of all regulations does not always result in the best decision. & 29.6 & -0.67 \\
\hline Cronbachs alpha & & 0.53 \\
\hline Second-order factor loading & & -0.48 \\
\hline \multicolumn{3}{|l|}{ Defining role as advocate } \\
\hline Internationally the Netherlands should lead the way in the protection of human rights. & 60.2 & 0.64 \\
\hline $\begin{array}{l}\text { The Refugee Convention and the European Convention of Human Rights represents one of } \\
\text { the most fundamental democratic values there is. }\end{array}$ & 75.5 & 0.66 \\
\hline $\begin{array}{l}\text { The Netherlands should definitely remain a safe haven for people persecuted in other coun- } \\
\text { tries. }\end{array}$ & 96.9 & 0.72 \\
\hline The importance of the protection of human rights vanishes in the present political climate. & 56.2 & 0.61 \\
\hline Abolishing the Refugee Convention would mean a setback for our present civilization. & 68.4 & 0.72 \\
\hline Cronbachs alpha & & 0.68 \\
\hline Second-order factor loading & & 0.65 \\
\hline Eigenvalue second-order factor & & 2.5 \\
\hline Percentage of the variance explained by the second-order factor & & 50.0 \\
\hline
\end{tabular}


Table 4. Factor and reliability analysis for conservatism (Percentages, first and second-order factor loadings, and Cronbachs alphas).

\begin{tabular}{|c|c|c|}
\hline & $\begin{array}{c}\text { \% agree } \\
\text { (strongly) }\end{array}$ & FI \\
\hline \multicolumn{3}{|l|}{ Authoritarianism } \\
\hline $\begin{array}{l}\text { Young people sometimes get rebellious ideas, but as they grow up, they ought to get over } \\
\text { them and settle down. }\end{array}$ & 13.2 & 0.66 \\
\hline $\begin{array}{l}\text { What this country needs most, more than laws and political programs, are a few courageous, } \\
\text { tireless, devoted leaders in whom the people can put their faith. }\end{array}$ & 7.2 & 0.46 \\
\hline Because of fast changes, it is difficult to know what is right and wrong. & 12.2 & 0.51 \\
\hline People can be divided into two distinct classes: the weak and the strong. & 3.1 & 0.59 \\
\hline $\begin{array}{l}\text { Most of our social problems would be solved if we could somehow get rid of immoral, } \\
\text { crooked, and feebleminded people. }\end{array}$ & 6.1 & 0.54 \\
\hline Most people disappoint when you get to know them better. & 3.0 & 0.58 \\
\hline If people would talk less and work more, everybody would be better off. & 10.3 & 0.75 \\
\hline Because of the many opinions about good and evil, it is unclear what to do. & 7.2 & 0.46 \\
\hline Cronbachs alpha & & 0.71 \\
\hline Second-order factor loading & & 0.78 \\
\hline \multicolumn{3}{|l|}{ Distrust in human nature } \\
\hline Most people are not really honest for a desirable reason; they're afraid of getting caught. & 15.3 & 0.69 \\
\hline People usually tell the truth, even when they know they would be better off by lying. & 8.2 & -0.47 \\
\hline $\begin{array}{l}\text { It's pathetic to see an unselfish person in today's world, because so many people take ad- } \\
\text { vantage of him. }\end{array}$ & 27.6 & 0.49 \\
\hline Most people would cheat on their income tax if they could gain by it. & 28.6 & 0.58 \\
\hline "Do unto others as you would have them do unto you" is a motto that most people follow & 27.6 & -0.62 \\
\hline $\begin{array}{l}\text { People claim that they have ethical standards regarding honesty, but few people stick to } \\
\text { them when the chips are down. }\end{array}$ & 32.7 & 0.69 \\
\hline Most people inwardly dislike putting themselves out to help other people. & 40.8 & 0.68 \\
\hline People pretend to care more about another than they really do. & 27.6 & 0.74 \\
\hline Cronbachs alpha & & 0.77 \\
\hline Second-order factor loading & & 0.68 \\
\hline \multicolumn{3}{|l|}{ Multiculturalism } \\
\hline Having many cultural groups in the Netherlands makes it difficult to develop a sense of unity. & 43.9 & -0.68 \\
\hline I find it hard to show understanding for customs of ethnic minorities. & 4.1 & -0.75 \\
\hline Dutch people can learn a lot of good things from ethnic minorities. & 64.3 & 0.75 \\
\hline The mixing of different minority groups unavoidably causes problems. & 53.1 & -0.56 \\
\hline Marriages between partners with a different ethnic background are doomed to fail. & 4.1 & -0.69 \\
\hline $\begin{array}{l}\text { In the present political climate too much emphasis is laid upon the problems caused by } \\
\text { foreigners. }\end{array}$ & 57.1 & 0.55 \\
\hline Cronbachs alpha & & 0.73 \\
\hline Second-order factor loading & & -0.86 \\
\hline \multicolumn{3}{|l|}{ Political party preference } \\
\hline Second-order factor loading & & 0.67 \\
\hline Eigenvalue second-order factor & & 1.8 \\
\hline Percentage of the variance explained by the second-order factor & & 60.1 \\
\hline
\end{tabular}


Table 5. Factor and reliability analysis of perceived economic threat (Percentages, factor loadings, and Cronbachs alpha).

\begin{tabular}{|c|c|c|}
\hline & $\begin{array}{c}\% \text { agree } \\
\text { (strongly) }\end{array}$ & FI \\
\hline In the future, I will be able to afford less luxury. & 26.5 & 0.61 \\
\hline Sometimes I worry that I will have to change my present way of living. & 17.3 & 0.40 \\
\hline The future will be better for the people than the present. & 6.1 & 0.48 \\
\hline My welfare will decrease in the coming years. & 24.5 & 0.65 \\
\hline The government does enough to increase the welfare of people like me. & 21.4 & -0.38 \\
\hline In one year, the economic situation in our country will have worsened. & 46.9 & 0.64 \\
\hline In the near future, there will be an economic crisis with high unemployment. & 16.5 & 0.66 \\
\hline Our country is wealthy at the moment. & 95.9 & -0.56 \\
\hline Cronbachs alpha & & 0.67 \\
\hline
\end{tabular}

\section{Appendix 2 Regression analyses and test for multicollinearity}

Table 6. Explanation of the extent to which decision makers take the information that is present on an asylum application for granted based on perceived work pressure, reputation, and experience (Correlates, bèta's, and variation inflation factors, $\mathrm{N}=97$ ).

\begin{tabular}{|l|c|c|c|c|c||}
\hline & $\mathbf{r}$ & $\mathbf{1}$ & $\mathbf{2}$ & \multicolumn{2}{|c|}{$\mathbf{3}$} \\
\hline & & & & & \multicolumn{2}{|c|}{ VIF } \\
\hline Perceived work pressure & $0.18^{\star \star}$ & $0.18^{\star \star}$ & & $0.24^{\star *}$ & 1.0 \\
Experienced employees & 0.08 & & 0.08 & 0.12 & 1.1 \\
Quality reputation decision maker & 0.10 & & 0.10 & 0.17 & 1.1 \\
\hline $\mathrm{R}^{2} \%$ & & 3.1 & 1.7 & 7.0 & \\
\hline
\end{tabular}

$$
{ }^{*} \mathrm{p}<0.10 \quad{ }^{* *} \mathrm{p}<0.05
$$

Table 7. Explanation of differences in deciding to grant a permit based on role definition, quality and kind of reputation, and background characteristics (Correlations, bèta's, and variation inflation factors, $\mathrm{N}=97$ ).

\begin{tabular}{|l|c|c|c|c|c|}
\hline \hline & $\mathbf{r}$ & $\mathbf{1}$ & $\mathbf{2}$ & \multicolumn{2}{|c|}{$\mathbf{3}$} \\
\hline & & & & & VIF \\
\hline Preference lenient asylum policy & $0.17^{\star *}$ & $0.18^{\star}$ & & $0.28^{\star *}$ & 2.0 \\
Quality reputation & -0.11 & -0.06 & -0.03 & -0.01 & 1.3 \\
Preference lenient asylum policy X quality reputation & $0.16^{\star}$ & $0.23^{\star *}$ & $-0.24^{\star *}$ & $0.21^{\star}$ & 1.2 \\
Reputation for being too restrictive & 0.11 & 0.17 & -0.06 & $0.20^{\star}$ & 1.5 \\
Experienced employees & -0.06 & & -0.03 & -0.07 & 1.1 \\
Professional past within the judicial system & $-0.21^{\star *}$ & & 0.10 & $-0.22^{\star *}$ & 1.3 \\
Former aid worker asylum seekers & -0.08 & & & -0.08 & 1.1 \\
Perceived economic threat & -0.03 & & & -0.01 & 1.3 \\
Conservatism & -0.02 & & & 0.24 & 2.4 \\
\hline $\mathrm{R}^{2 \%}$ & & 9.5 & 5.7 & 17.4 & \\
\hline
\end{tabular}

$$
{ }^{*} \mathrm{p}<0.10 \quad{ }^{* *} \mathrm{p}<0.05
$$




\section{Notes}

The data reported on is current to the fall of 2002.

1. Keith Hawkins, The Uses of Discretion (Oxford: Clarendon Press, 2001).

2. Roy Sainsbury, "Administrative Justice: Discretion and Procedure in Social Security Decision-Making," in The Uses of Discretion, ed. Keith Hawkins (Oxford: Clarendon Press, 2001), 297-8.

3. Decision makers base their decisions on data that have been collected by others.

4. Monika Smit, "De komst van jonge alleenstaande asielzoekers en hun asielprocedure" [The Arrival of Young Unaccompanied Asylum Seekers and Their Asylum Procedure], Familie- en jeugdrecht 20 (1998): 174-180.

5. Elspeth Guild, Moving the Borders of Europe (Nijmegen: Katholieke Universiteit Nijmegen, 2001).

6. Thomas Holzer, Gerald Schneider, and Thomas Widmer, "Discriminating Decentralization: Federalism and the Handling of Asylum Applications in Switzerland, 19881996," Journal of Conflict Resolution 44 (2000): 250-76.

7. Peter Mascini, "Regionale Verschillen in Uitvoering Van Asielbeleid" [Regional Differences in Carrying Out Asylum Policy], Sociologische Gids 49 (2002): 292-312.

8. N. Doornbos and J.P.P. Sellies, Het overlegmodel in de asielprocedure: een onderzoek naar de werking van het overlegmodel in het aanmeldcentrum Schiphol en de onderzoeks- en opvangcentra Oisterwijk en Schalkhaar [The Deliberation Model in the Asylum Procedure: An Evaluation of the Deliberation Model in the Application Center Schiphol and the Asylum Seekers Centers Oisterwijk and Schalkhaar] (Nijmegen: Instituut voor Rechtssociologie, 1997).

9 . William Branigin, "Nation's Political Asylum System Draws Criticism from Both Sides: Handling of Contrasting Cases Illustrates Inconsistency in Process," Washington Post, July 7, 1996; Nienke Doornbos De papieren asielzoeker: institutionele communicatie in de asielprocedure [The Paper Asylum Seeker: Institutional Communication in the Asylum Procedure] (Nijmegen: GNI, 2003); Nienke Doornbos and Leny E. de Groot-van Leeuwen, "Vierentwintiguursbeslissingen over asielzaken" [Fast Track Decisions on Asylum Applications], Migrantenstudies 14 (1998): 233-247; Doornbos and Sellies.

10. But see: Doornbos and De Groot-Van Leeuwen.

11. Michael Lipsky, Street-Level Bureaucracy: Dilemmas of the Individual in Public Services (New York: Russell Sage Foundation, 1980).

12. Janet A. Gilboy, "Deciding Who Gets In: Decisionmaking by Immigration Inspectors," Law and Society Review 25 (1992): 571-599.

13. Carolyn L. Clark-Daniels and Steven R. Daniels, "StreetLevel Decision Making in Elder Mistreatment Policy: An Empirical Case Study of Service Rationing," Social Science Quarterly 76 (1995): 460-73.

14. Gilboy.
15. Robert M. Emerson and Blair Paley, "Organizational Horizons and Complaint-Filing," in The Uses of Discretion, ed. Keith Hawkins (Oxford: Clarendon Press, 2001), 234.

16. Keith Hawkins, "Fatcats' And the Prosecution in a Regulatory Agency: A Footnote on the Social Construction of Risk," in Organizations, Uncertainties and Risk, ed. James F. Short, Jr., and Lee Clarke (Boulder, San Francisco, and Oxford: Westview Press, 1992).

17. Sarah Brants, "De macht van het onderhandelen: de penitentiair inrich-tingswerker als street-level bureaucrat" [The Power to Negotiate: The Prison Worker as Street-level Bureaucrat], Amsterdams Sociologisch Tijdschrift 30 (2003): 349-365.

18. Lipsky.

19. Naomi Kroeger, "Bureaucracy, Social Exchange, and Benefits Received in a Public Assistance Agency," Social Problems 23 (1975): 182-96.

20. Geneviève Bouchard and Barbara Wake Carroll, "PolicyMaking and Administrative Discretion: The Case of Immigration in Canada," Canadian Public Administration 45 (2002): 239-57.

21. Leanne Weber, "Down That Wrong Road: Discretion in Decisions to Detain Asylum Seekers Arriving at UK Ports," Howard Journal 42 (2003): 248-62.

22. Chris Argyris, "Theories of Action That Inhibit Individual Learning," American Psychologist 31 (1976): 638-54.

23. Patrick G. Scott, "Assessing Determinants of Bureaucratic Discretion: An Experiment in Street-Level Decision Making," Journal of Public Administration Research and Theory 7 (1997): 35-57; James Q. Wilson, Bureaucracy: What Government Agencies Do and Why They Do It (New York: Basic Books, 1989).

24. Sainsbury.

25. Susan Edwards and Ann Halpern, "Regional "Injustice: Financial Provision on Divorce," Journal of Social Welfare Law 2 (1990): 71-88.

26. Anita Böcker and Lilian Clermonts, Poortwachters van de Nederlandse arbeidsmarkt: arbeidsvoorziening en de verlening van tewerkstellingsvergunningen [Gatekeepers of the Dutch Labor Market: Labor Provision and the Granting of Labor Permit] (Nijmegen: Katholieke Universiteit, Faculteit der rechtsgeleerdheid, 1995).

27. Simon Halliday, "Institutional Racism in Bureaucratic Decision-Making: A Case Study in the Administration of Homeless Law," Journal of Law and Society 27 (2000): 44971.

28. Kroeger.

29. Saad Z. Nagi, "Gate-Keeping Decisions in Service Organizations: When Validity Fails," Human Organization 33 (1974): 47-58.

30. Yaël Vinckx, "De bunkermentaliteit van de IND" [The Bunker Mentality of the IND], NRC-Handelsblad, February 2, 1998.

31. Clarence N. Stone, "Attitudinal Tendencies among Officials," in The Public Encounter: Where State and Citizen 
Meet, ed. Charles T. Goodsell (Bloomington: Indiana University Press, 1981).

32. Wilson.

33. Peter K. Manning, "Police Lying," Urban Life and Culture 3 (1974): 283-306.

34. Stone, 50.

35. Dick Houtman, "Welfare State, Unemployment, and Social Justice: Judgments on the Rights and Obligations of the Unemployed," Social Justice Research 10 (1997): 267-88.

36. Peter Burns and James G. Gimpel, "Economic Insecurity, Prejudicial Stereotypes, and Public Opinion on Immigration Policy," Political Science Quarterly 115 (2000): 201-25; Christian Dustmann and Ian Preston, "Racial and Economic Factors in Attitudes to Immigration," Social Science Research Network, Working Papers Series (2000).

37. Scott.

38. F. Fleurke, and P.J. de Vries, "Bureaucratie presteert beter op maatwerk" [Custom Making Results in Better Achievements for Bureaucracies], Bestuurskunde 6 (1998): 297319.

39. Mascini.

40. As a result of the deliberate choices, the variation in decisions in the present case is probably greater than in the average asylum application. This means that this research cannot answer the question regarding the extent to which the implementation of asylum policy results in inequality before the law. However, as stated in the introduction, the aim of the present study was to trace causes for this.

41. Bert Jetten and Michiel Pat, Werkdruk en welzijn in het werk [Work Pressure and Wellbeing on the Job] (Assen: Van Gorcum, 1999).

42. The item "Do you generally have enough time to finish your job" loads negatively on the "perceived work pressure" factor. This item was therefore multiplied by minus 1 , just like any other item with a negative factor loading.

43. Only 5.1 per cent of all caseworkers knew the number of appeals filed with the IND against their decisions and their outcome, while just 8.2 per cent knew this with respect to the number of appeals filed with the appellate court. Employees who knew of none of the outcomes were given the score of 0 for the proportion because as long as employees are not aware of the outcomes on appeals it is unlikely that these will influence their decisions.

44. T.W. Adorno, E. Frenkel-Brunswik, D.J. Levinson, and R.N. Sandford, The Authoritarian Personality (New York: Harper \& Row, 1950).

45. See, for example, Dick Houtman, Class and Politics in Contemporary Social Science: "Marxism Lite" and Its Blind Spot for Culture, Sociological Imagination and Structural Change (New York: Aldine de Gruyter, 2003).

46. There are two reasons why the category "people with a preference for a right-wing party" can be combined with the category "doubters and non-voters." First, it has been demonstrated that new right-wing parties attract a lot of former non-voters. M. Minkenberg, "The New Right in Germany:
The Transformation of Conservatism and the Extreme Right," European Journal of Political Research 22 (1992): 55-81; R. Eatwell, "The Rebirth of the 'Extreme Right' in Western Europe?” Parliamentary Affairs 53 (2000): 407-25. Second, factor analyses based on political party preference, authoritarianism, distrust in human nature, and multiculturalism showed that the factor loadings of these two categories differ little: (1) Green Left Party, Socialist Party, or considering either the Green Left Party and the Social Democratic Party (-0.47); (2) Social Democratic Party or Democratic Party (-0.12); (3) Doubters and non-voters (0.22); (4) Republican Party, Christian Democratic Party, Christian Union (0.57).

47. Lawrence S. Wrightsman, Assumptions About Human Nature: Implications for Researchers and Practitioners, $2 \mathrm{nd}$ ed. (California, London, and New Dehli: Sage Publications, 1992).

48. F. van Vlaardingen, Culturele veranderingen in Nederland 1992 [Cultural Changes in the Netherlands 1992] (Codeboek P1152) (Amsterdam: Steimetzarchief, 1994).

49. Ronald R. Hocking, Methods and Applications of Linear Models: Regression and the Analysis of Variance (New York, Chichester, Brisbane, Toronto, and Singapore: John Wiley \& Sons, 1996), 274.

50. Burns and Gimpel; Dustmann and Preston.

51. Mark Elchardus and Jessy Siongers, "Racisme, een kwestie van smaak? Een onderzoek bij jongeren uit het $4 \mathrm{e}$ en $6 \mathrm{e}$ jaar secundair onderwijs in Vlaanderen," [Racism, a Matter of Taste? A Study among Adolescents from the Fourth and Sixth Grade of Secondary Education in Flanders], Sociologische Gids 50 (2003): 259-284.

52. Marcel Coenders, Marcel Lubbers, and Bas van de Meerendonk, "Similarities and Differences in Exclusionism: Attitudes towards Ethnic Minorities and Lesbians and Gay Men" (paper presented at the Marktdag sociologie, May 22, 2003, Nijmegen).

53. Bernd Schünemann and Wolfgang Bandilla, "Perseverance in Courtroom Decisions," in Criminal Behavior and the Justice System: Psychological Perspectives, ed. Hermann Wegener, Friedrich Lösel, and Jochen Haisch (New York: Springer-Verlag, 1989).

54. Doornbos.

55. Weber, 257.

56. Lipsky.

57. Thomas Spijkerboer, "De afdeling en de rechtsstaat: het hoger beroep in vreemdelingenzaken" [The High Court and the Constitutional State: The Court of Appeal in Asylum Cases], Nederlands juristenblad 42 (2002): 2082-2088.

58. Mascini.

59. Erik Snel, Jan de Boom, and Godfried Engbersen, "Migration and Migration Policy in the Netherlands," Report for the Continuous Reporting System on Migration (SOPEMI) of the Organisation of Economic Co-operation and Development (OECD) (Rotterdam: Ercomer-EUR/ RISBO/ Erasmus University, 2003). 
60. Human Rights Watch, Fleeting Refuge: The Triumph of Efficiency over Protection in Dutch Asylum Policy, vol. 15 (Washington, London, and Brussels, 2003).

61. Lipsky, 197.

Peter Mascini is an assistant professor of sociology at Erasmus University of Rotterdam, the Netherlands, and a member of the Amsterdam School for Social Science Research (ASSR). His research focuses on the legitimation, application, and enforcement of rules, policy instruments and laws. A recent article he wrote with Marjolein van Bochove on gender and asylum has been published in International Migration Review.
The research on which this paper is based is part of a larger research project about differences in the implementation of asylum policy that was made possible by fellowships of the Dutch Organization for Scientific Research (NWO) and of the Erasmus University of Rotterdam. This research would not have been possible without the cooperation of the Dutch Immigration and Naturalization Service (IND), especially of the unit managers and the asylum caseworkers. I want to thank all of them, but, of course, the responsibility for the content of this paper is entirely mine. 